\title{
CheKan YURII
}

https://orcid.org/0000-0002-1501-1592

Tchaikovsky National Music Academy of Ukraine (Kyiv, Ukraine)

y.chekan@gmail.com

\section{ZOLTAN KODÁLY AND STANISLAV LYUDKEVYCH}

There is a fairly rich base for comparing Kodály (1882-1967) and Lyudkevych (18791979). Both musicians were from one generation, shared their social background and received the same education. They had the same areas of their professional implementation. Both musicians represent ancient musical cultures that were freed from imperial influence in the early 20th century. If Hungarian culture got rid of the German influence, then Ukrainian culture fell under Soviet pressure, remaining colonial. This explains mainly the difference in the methods and results of the implementation of folk, composer, pedagogical work of Kodály and Lyudkevych.

Key words: comparison, universal personality, Zoltan Kodály, Stanislav Lyudkevych, Hungarian and Ukrainian musical culture.

The connections of the creative activity of the outstanding Hungarian musician Zoltan Kodály with the Ukrainian musical culture can be studied both in genetic and in typological aspects. In the first case, attention is focused on the impact that Kodály has had on Ukrainian composers and folklorists, on the impact of the Kodály musical and pedagogical system on the mass musical education in Ukraine. In the second - the attention of the researcher is concentrated on possible parallels in the development of national musical cultures, elucidation of their coinciding and differing features. Most clearly such parallels, coincidences and differences are revealed in the comparison.

The very idea of comparing the two composers in musicology is far from new [1, $345-349 ; 8,12-13]$. Common place here are comparisons of the creative figures of contemporary composers, for example, Palestrina (1514-1594) and Orlando Lasso (1532-1594); Bach (1685-1750) and Handel (1685-1759); Chopin (1810-1849) and Schumann (1810-1856); Tchaikovsky (1840-1893) and Mussorgsky (1839-1881) etc. Each time, as a result of comparison, we find out what unites them. This, usually, lies on the surface: the Renaissance polyphonic style of Palestrina and Lasso; the embodiment of the principles of baroque in the music of Bach and Handel; the romantic essence of the works of Chopin and Schumann; belonging to the first Russian classical composers' school by Tchaikovsky and Mussorgsky. But, finding out the general, we clearly understand the subtle differences. For example, comparing the legacy of Mussorgsky and Tchaikovsky, we see not only the operation of the general principles of the Russian composer school of the second half of the nineteenth century (democratism and nationality), but also differentiate their specific manifestations in the work of the abovenamed composers - supporters of the Russian imperial idea, Uvarov's triad "orthodoxablosutism-nationality", having a similar origin (impoverished nobles), a similar biographical trajectory (the first non-music education, official / military service, the subsequent concentration on music). With the general identification of democracy 
through the dominance of genres of "program" music, based not only on purely musical (intonational), but also on the literary (verbal) semiotic organization. These are the genres of opera, program symphonic opuses and romance. They constitute the genre basis of the heritage of both Mussorgsky and Tchaikovsky. But, in the case of common genres, their varieties are fundamentally different, characteristic for one and the other composer. Tchaikovsky tends to lyric-psychological opera, generalized symphonic programming and lyrical romance. Mussorgsky - to the historical epic opera, plot program and theatrical romance. If we talk about the second coordinate - "nationality", then the common for both composers relies on the orientation of the popular and speech intonations Mussorgsky's orientation on the peasant song and common parlance, and Tchaikovsky - on the urban romance and prosody, typical for the Moscow manor nobility. The explanation of these subtle differences with a common foundation is the task of the historian of music; in this case, much is due to the Slavophile ideological orientation of Mussorgsky and the European - Tchaikovsky. The example given is a dotted comparison of contemporaries composers belonging to one national culture. Such comparisons are very fruitful when choosing contemporaries belonging to different national schools. However, in this case, you need to very carefully justify the choice of the pair for comparison.

Which of the Ukrainian composers - contemporaries Zoltan Kodály - is the most relevant figure for comparison?

Let's consider one of the possible options.

The activities and creativity of Zoltan Kodály evokes numerous parallels, for example, with the figure of Mykola Leontovych (1877-1921), an outstanding Ukrainian musician of the first decades of the twentieth century, known throughout the world for virtuoso processing of the Ukrainian calendar song Shchedryk. Just like Kodály, Leontovych devoted his entire life to the development of the national musical culture. Just like Kodály, he was an outstanding musician-teacher, folklorist, composer, public figure. Parallel Leontovych / Kodály can continue: the musical and pedagogical system of both relies on national folklore and the idea of choral singing; one of the central genres of composer creativity of both is the processing of folk songs; public activity, and Kodály, and Leontovych, his goal is to establish a broad musical education. His first collection of folk songs ("Pisni z Podillya") Leontovych publishes in 1901, shortly before the appearance of the collections Kodály and Bartok (1906). However, despite such obvious parallels, the comparison of the figures of Kodály and Leontovych, in our opinion, is not entirely correct. First of all, they belong to different layers of society: Kodály is the son of an official of the Hungarian state railways, only a part of the childhood lived in the village (it is a multinational Galante, where Kodály lived for 7 years, until 1892, where there were 2 schools and 2 castles princes Esterházy and an important railway junction on the Budapest-Vienna line). Leontovych - the son of a village priest, spent his childhood in the village of Shershni in Podillya. The village consisted of only 77 households, and to the nearest railway station was $20 \mathrm{~km}$. The difference in social origin has several consequences. First, the level of preparation of Kodály and Leontovych essentially differs: the fundamental linguistic education received at the Budapest University and the musical at the Royal Hungarian Academy of Music on the one hand, and the Theological Seminary, as well as private lessons in music theory from Boleslav Yavorsky other. Secondly, the working conditions of these composers were very different. Kodály was a professor at the Royal Academy of Music in the capital; Leontovych - a teacher of music and singing in rural schools in Podillya (Vinnitsa region), railway - in the Donbass, as well as in the diocesan women's school in the provincial Tulchyn. Short-term teaching in 
Kiev (Music and Drama Institute named after Lysenko) was interrupted by the occupation of Kiev by General Denikin's troops, and Leontovych was forced to flee to the province, to Tulchin. Thirdly, fate did not give Leontovych the opportunity to realize his talent - only after he started working on the opera "Na Rusalchin Velikden" he was killed; at the same time, Kodály lived a long life and realized his talent to the fullest extent, being part of the elite of Hungarian society, the President of the Hungarian Academy of Sciences.

It is also possible to find parallels and convergence in the activities of Kodály and Filaret Kolessa (folklorist, composer), Kodály - and Alexander Koshyts (folklorist, composer, choral conductor). But still the most obvious analogies arise when comparing the figures of Kodály (1882-1967) and Stanislav Lyudkevych (1879-1979).

The grounds for comparing precisely these personalities are numerous.

Both musicians belonged to the same generation, had a similar social origin and received a similar education [2, 251-252; 11, 8-42]. Let us dwell on these questions in more detail.

The most obvious are the facts connected with the social origin and fundamentality of the academic education of Kodály and Lyudkevych.

Kodály is the son of a railway official, that is, a representative of the middle class; the same can be said about Lyudkevych - the son of a gymnasium teacher. Both families supported the traditions of home music making; both composers associate their first musical impressions with home evenings when parents and their guests play music; both their first music lessons were received from their mothers. The traditions of this social stratum include aspiration and the opportunity to give children a good university education. Here we come to another surprising parallel Kodály / Lyudkevych: they both received a brilliant education combining university philological and musical training. Thus, having graduated with honors from the gymnasium in Nagyszombat (1900), Kodály, as is known, goes to the philological faculty of the University of Budapest and to the State Hungarian Music Academy and finishes them brilliantly. Lyudkevych's fate is similar: after graduating from the Gymnasium in Yaroslav (1897), he enrolled at the Faculty of Philosophy (Department of Ukrainian and Classical Philology) of Lviv University, where he studied from 1897 to 1901. In parallel, Lyudkevych studies at the Conservatory of the Galician Musical Society (1897-1899), and later, from 1906 to 1908 , he improves at the Vienna University of Music and Performing Arts under the direction of Guido Adler. Along with Adler, he is engaged in composition with Alexander Zemlinsky and polyphony with Herman Gredener. Parallels are obvious; it is equally obvious that both musicians realized their life purpose during the gymnasium years; both from the gymnasium years took part in music making - the choral one first of all (this is a kind of initium of their musical path) - and both complete the period of formal education with the defense of doctoral dissertations: Kodály on the Hungarian song strophic (1907), Lyudkevych on the development of sound-image in music (1908). Here it is necessary to mention that this thesis is not the first scientific study by Lyudkevych. Even while studying at the university, he wrote several works, among which the study "Barshchina and its abolition in the Russian-Ukrainian folk songs" (1898) should be mentioned. In this work, Ukrainian musical folklore is considered as a national phenomenon, with the identification of deep features of commonality between Galician-Ukrainian and CentralUkrainian peasant songs. Another Lyudkevych's work of University period is the study "About the basis and significance of song in the poetry of Taras Shevchenko" (1901). In this study Lyudkevych comes to the conclusion that the stylistic features of Shevchenko's poetry are based on the implementation of the features of the Ukrainian folk song - its 
stylistic parallels, alliteration, incomplete rhymes, inconsistency of grammatical and rhythmic accents [9]. And the main link that unites poetry and music, Lyudkevych calls rhythm. The direction of Kodály's scientific research is similar; we will quote a fragment from the introductory chapter of his doctoral dissertation: "The vocal text of a folk song really only lives in a sung song. A text without a melody is not a complete work. And from two creative elements, the melody is even more important, because it is more primitive and more stable ... To explore in folk songs requires first and foremost rhythm - based on singing" [11, 34].

Analyzing the creative path of both musicians, we come to an obvious conclusion about the complete coincidence of the spheres of their further professional realization. At the same time, it should be emphasized that both Kodály and Lyudkevych did not have one - the dominant - sphere of musical interests. Different areas of their activities act as complementary and mutually reinforcing. Such a breadth of professional interests characterizes Kodály and Lyudkevych as universal personalities. As is known, the core of the personality, its "psychological profile" forms a hierarchy of activities. In this case, the universal personality is one for which more than one leading activity is characteristic. Both musician, Kodály and Lyudkevych, equally successfully realized themselves in folkloristics, composer creativity, musical pedagogy, music-critical and journalistic activities.

As folklorists, both Kodály and Lyudkevych became pioneers (each in their national culture) in deciphering folk songs from phonographic rollers. Lyudkevych spent 4 years of his life from 1902 to 1906 - deciphering phonographic records made in 19001902 by a member of the Shevchenko Scientific Society (NST), ethnographer and linguist Joseph Rozdolsky (1872-1945). For four years, Lyudkevych deciphered 1526 folk songs recorded by Rozdolsky, edited them and published them in two volumes under the title "Galician-Russian folk melodies". All the songs in this compendium are grouped according to the genre principle, and in the middle of individual genre groups - according to rhythm, as a common element of the musical and poetic structure of the song [9; 12].

Folklore activity is the foundation of compositional creativity Kodály and Lyudkevych. As composers, they concentrated primarily on vocal-symphonic and orchestral genres, chamber-instrumental music, folk song processing. At the same time, it must be recognized that Lyudkevych, having formed in the era of late romanticism, remains faithful to "national romanticism" throughout his life. He did not accept stylistic innovations of the early twentieth century; his main creative discoveries (cantata symphony "The Caucasus", symphonic poems "Moses", "Kameniary", piano "Elegy", etc.) were made in the early period of creativity (until 1919), and later his style is preserved and he remains a singer of the last century of romanticism in the twentieth century, preserving the stylistic standards found at the beginning of his creative way.

Finally, it is necessary to name one more important sphere of activity of Kodály and Lyudkevych - musical pedagogy. Both musicians paid special attention to the development of hearing through choral singing, they placed the emphasis on the formation of a solfeggio musician, based on the material of national folklore - and this unites them. At the same time, Kodály devotes his life to the development of mass musical education, creates an innovative method of teaching music, based on the Hungarian folk song, its unique modal features. Lyudkevych also paid much attention to musical pedagogy aimed at training professional musicians; from here - special attention to academic disciplines (music theory, solfeggio, harmony), as well as a series of articles on the problems of organizing the Ukrainian Conservatory in Lviv, on reforming the Higher Musical Institute Lysenko and about the musical and pedagogical activity of his branches. 
Folklore for Lyudkevych is a material that must be selected to illustrate the commonly used norms and rules of the "school" theory of music. If one compares his position with Kodály's position, then one can say that Kodály's method grows from Hungarian folklore, and Lyudkevych's position consists in adaptation, adaptation of national folklore to allEuropean norms.

The point deserving a separate mention is the music-critical and journalistic activities of both musicians. Both raised in the pages of the press the burning questions of the current musical life; for Kodály the most important topics are topics related to the specific character of the Hungarian folk song, mass musical education, educational materials. Lyudkevych in the pre-war Galicia is one of the chroniclers of the musical life of Lviv - with a special emphasis on the Ukrainian component of it.

The most complex and ambiguous, in our opinion, is the thesis of Kodály and Lyudkevych's belonging to the same generation. Formally, they are peers: Lyudkevych is three years older, and such a small age difference could be ignored. However, belonging to the mental generation is determined not only by the physical age of the person, not only by the year of his birth, but also by the phase, the stage of development of the culture to which he belongs and which he creates.

It is generally recognized that Kodály, together with Bartok, became the founders of the new Hungarian music. They have behind them the national-romantic Hungarian musical culture of the nineteenth century: the romantic Hungarian opera of Ferenc Erkel, the romantic instrumentalism of Franz Liszt and Mihai Moshony [6, 74-83]. They have a developed national infrastructure of musical life of the European type behind them: in 1853 the Philharmonic Society was founded in Budapest, in 1875 - the State Musical Academy was opened, and in 1884 - the Budapest Opera [6, 83-87]. Finally, they have a national state behind them: after February 1867, the creation of a dualistic AustroHungarian monarchy with its royal and imperial parts, Hungary gained real autonomy it was separated from Austria by a state structure, legislation and administration. Further historical conflicts of the twentieth century (the Three Hungarian Republics, the Kingdom of Hungary) did not change this situation - Hungary remained a truly sovereign state with its own cultural policy. Thus, conditions were created for the formation and development of a new national culture - it was this mission in the field of music that was headed by Bartok and Kodály.

The situation with Ukraine was completely different. Ukraine, its people and its lands were divided among several states. Naddnipryanshchina was part of the Russian Empire, then - the USSR. Galicia - in the Austrian part of Austria-Hungary, then Poland. Bukovina - in the composition of Austria-Hungary, then - Romania. Transcarpathia - in the composition of Austria-Hungary, then - Czechoslovakia. Volyn - as part of the Russian Empire, then - Poland [7, 135-247]. Such a tragic divorce, the absence of state institutions that protect national interests, the lack of the infrastructure of musical life, all set other tasks for Ukrainian musicians. First of all, the task of realizing the national identity and preserving the national identity. It is the key one for Ukrainian musicians of the Romantic era, to which Stanislav Lyudkevych belongs.

Very indicative in this regard is the comparison of two texts belonging to Kodály and Lyudkevych and created in 1906 - prefaces to the collections "Hungarian folk songs for voice accompanied by pianoforte" and "Galician-Russian folk melodies". The main goal of the collection, which Kodály declares is familiarizing the public with the folk song, the creation of a concert repertoire of Hungarian songs in the treatments: "We need to select the best and bring it closer to the tastes of the audience with the help of some kind of musical processing" $[3,22]$. Lyudkevych sets other tasks: after discussing methodological issues of decoding, 
systematization, etc., he concentrates on the characteristic features of Ukrainian songs of Galicia, their similarities and differences with the songs of Lemkovshchina and Naddnepryanshchina, and other influences (primarily Polish ones) [4].

Concluding, I emphasize that both musicians - representatives of ancient national musical cultures, at the beginning of the twentieth century emerged from under imperial influence. And if the Hungarian culture in the conditions of an independent state thanks to Bartok and Kodály freed from German influence, the Ukrainian (in particular Galician), "leaving" from Austria-Hungary, fell under the Soviet press and remained colonial. This largely explains the differences in the ways of realization and concrete results of folklore, composer, pedagogical and educational activities of Kodály and Lyudkevych, outstanding sons of their people.

\section{Bibliography}

1. Bukofzer Manfred F. Music in the Baroque Era from Monteverdi to Bach. N.Y.: W. W. Norton \& Company. Inc., 1947. 489 p.

2. Кияновська Л. Галицька музична культура XIX-XX століття. Чернівці: Книги XXI, 2007. 424 c.

3. Кодай 3. Избранные статьи / Пер. с венг. П. Ф. Вейса. Москва: Советский композитор, 1982. 288 с.

4. Людкевич С. Дослідження, статті, рецензії. Т. 1. Львів: М. П. Коць, 1999. 495 с.

5. Людкевич С. Дослідження, статті, рецензії, виступи. Т. 2. Львів: М. П. Коць, 2000. $815 \mathrm{c}$

6. Сабольчи Б. История венгерской музыки. Будапешт: Корвина, 1964. 246 с.

7. Снайдер Т. Перетворення націй. Польща, Україна, Литва, Білорусь. 1569-1999 / Пер. 3 англ. А. Котенко, О. Надтока. Київ: Дух і Літера, 2012. 464 с.

8. Чекан Ю. Музикознавча компаративістика: від методу - до науки // Музикознавчі студії Інституту мистецтв Волинського національного університету імені Лесі Українки та Національної музичної академії України імені П. І. Чайковського. Луцьк, 2012. Вип. 10. C. 6-18.

9. Штундер 3. Станіслав Людкевич. Життя і творчість. Т. I (1879-1939). Львів : ПП «Бінар», 2005. 635 с.

10. Штундер 3. Станіслав Людкевич. Життя і творчість. Т. II (1939-1979). ЛьвівЖовква: Місіонер, 2009. 360 с.

11.Эсе Л. Золтан Кодай: День за днем / Пер. с венг. Г. С. Лейбутина. Москва: Музыка, 1980. 269 с.

12. Якубяк Я. Микола Лисенко і Станіслав Людкевич. Львів: ДВЦ НТШ, 2003. 263 с.

\section{References}

1. Bukofzer, Manfred F. (1947). Music in the Baroque Era from Monteverdi to Bach. N.Y.: W. W. Norton\&Company. Inc., 489 p. [in English].

2. Kyianovska, L. (2007). Galician music culture of the nineteenth and twentieth centuries. [Halytska muzychna kultura XIX-XX stolittia]. Chernivtsi: Knyhy - XXI, 424 p. [in Ukrainian].

3. Kodaj, Z. (1982). Featured Articles [Izbrannye stat'i]. Moscow: Sovetskij kompozitor, 288 p. [in Russian].

4. Liudkevych, S. (1999). Research, articles, reviews [Doslidzhennia, statti, retsenzii]. T. 1. Lviv: M. P. Kots, 495 p. [in Ukrainian]. 
5. Liudkevych, S. (2000). Research, articles, reviews, speeches [Doslidzhennia, statti, retsenzii, vystupy]. T. 2. Lviv: M. P. Kots, 815 p. [in Ukrainian].

6. Sabol'chi, B. (1964). History of hungarian music [Istorija vengerskoj muzyki]. Budapesht: Korvin, 246 p. [in Russian].

7. Snaider, T. (2012). The transformation of nations. Poland, Ukraine, Lithuania, Belarus. 1569-1999 [Peretvorennia nacii. Polshcha, Ukraina, Lytva, Bilorus. 1569-1999]. Kyiv: Dukh i Litera, 464 p. [in Ukrainian].

8. Chekan, Yu. (2012). Musical Comparative Literature: From Method to Science [Muzykoznavcha komparatyvistyka: vid metodu - do nauky]. Music Studies Studies at the Institute of Arts of the Volyn National University named after Lesya Ukrainka and the National Music Academy of Ukraine named after P. I. Tchaikovsky [Muzykoznavchi studii Instytutu mystetstv Volynskoho natsionalnoho universytetu imeni Lesi Ukrainky ta Natsionalnoi muzychnoi akademii Ukrainy imeni P. I. Chaikovskoho], vol. 10, pp. 6-11 [in Ukrainian].

9. Shtunder, Z. (2005). Stanislav Lyudkevich. Life and creativity. T. I (1879-1939) [Stanislav Liudkevych. Zhyttia i tvorchist. T. I (1879-1939)]. Lviv: PP «Binar», 635 p. [in Ukrainian].

10. Shtunder, Z. (2009). Stanislav Lyudkevich. Life and creativity. T. II (1939-1979) [Stanislav Liudkevych. Zhyttia i tvorchist. T. II (1939-1979)]. Lviv-Zhovkva: Misioner, 360 p. [in Ukrainian].

11. Jese, L. (1980). Zoltan Kodai. Day after day [Zoltan Kodaj: Den'za dnem]. Moscow: Muzyka, 269 p. [in Russian].

12. Yakubiak, Ya. (2003). Mykola Lysenko and Stanislav Lyudkevich [Mykola Lysenko i Stanislav Liudkevych]. Lviv: DVTs NTSh, 263 p. [in Ukrainian].

Стаття надійшла до редакції 10.12.2018 р.

\section{ЧЕКАН Ю. I.}

https://orcid.org/0000-0002-1501-1592

Національна музична академія України ім. П. І. Чайковського (Київ, Україна)

y.chekan@gmail.com

DOI: https://doi.org/10.31318/2522-4190.2019.124.165421

\section{Золтан Кодай та Станіслав Людкевич}

Актуальність дослідження зумовлюється кількома факторами. Поперше, науковою невідрефлектованістю особливостей розвитку української та угорської музичної культури на етапі їх звільнення з-під імперського тиску. Подруге, необхідністю подальшого розвитку конкретних компаративних досліджень у вітчизняному музикознавстві. По-третє, недослідженістю типологічних паралелей «Кодай - Людкевич».

Мета дослідження - з'ясувати збіги та відмінності творчої реалізації видатних сучасників - 3. Кодая та С. Людкевича, проаналізувавши їхні конкретні прояви.

Методологія дослідження. У даній статті застосовано біографічний метод та типологічні порівняння на рівні аналізу творчої реалізації конкретних особистостей. 
Підстави для порівняння саме фігур З. Кодая (1882-1967) та С. Людкевича (1879-1979) численні. Обидва музиканти належали до одного покоління, мали подібне соціальне походження та отримали однакову освіту (окрім музичної, обидва мали університетську філологічну підготовку). Окрім того, повністю співпадають сфери їх професійної реалізації: фольклористика, композиторська творчість, музична педагогіка, музично-критична та публіцистична діяльність. Як фольклористи, Кодай та Людкевич стали піонерами (кожен у своїй національній культурі) у справі розшифровки народних пісень з фонографічних валиків. Як композитори, вони концентрувалися передусім на вокально-симфонічних та оркестрових жанрах, обробках народних пісень; фундамент їх індивідуального стилю утворює опора на національний фольклор. Як музичні педагоги, обидва приділяли особливу увагу розвитку слуху через хоровий спів. Як музичні критики та публіцисти - піднімали на сторінках преси нагальні питання поточного музичного життя.

Основні результати та висновки дослідження. 3. Кодай та С. Людкевич - представники древніх національних музичних культур, які на початку XX століття вийшли з-під імперського впливу. I якщо угорська культура в умовах незалежної держави завдяки Б. Бартоку та З. Кодаю звільнилась від німецького впливу, то українська (зокрема галицька), «уходячи» від Австро-Угорщини, потрапила під радянський прес і залишилась колоніальною. Цим, зокрема, пояснюються відмінності способів реалізації та конкретних результатів фольклористичної, композиторської, педагогічної та просвітницької діяльності 3 . Кодая та С. Людкевича - видатних синів своїх народів.

Ключові слова: порівняння, універсальна особистість, Золтан Кодай, Станіслав Людкевич, угорська та українська музична культура.

\section{ЧЕКАН Ю.И.}

https://orcid.org/0000-0002-1501-1592

Национальная музыкальная академия Украины

им. П. И. Чайковского (Киев, Украина)

y.chekan@gmail.com

\section{ЗОЛТАН КОДАЙ И СТАНИСЛАВ ЛЮДКЕВИЧ}

Актуальность исследования обусловливается несколькими факторами. Во-первых, научной неотрефлектированностью особенностей развития украинской и венгерской музыкальной культуры на этапе их освобождения из-под имперского влияния. Во-вторых, необходимостью дальнейшего развития конкретнвых компаративных исследований в отечественном музыкознании. В-третьих, неисследованностью типологических параллелей «Кодай - Людкевич».

Цель исследования - выяснить совпадения и отличия творческой реализации выдающихся современников - З. Кодая и С. Людкевича, проанализировав их конкретные проявления.

Методология исследования. В данной статье использован биографический метод и типологические сравнения на уровне анализа творческой реализации конкретных личностей. 
Основания для сравнения именно фигур З. Кодая (1882-1967) и С. Людкевича (1879-1979) многочисленны. Оба музыканта принадлежали к одному поколению, имели сходное социальное происхождение и получили одинаковое образование (помимо музыкального, оба имели университетскую филологическую подготовку). Кроме того, полностью совпадают сферы их профессиональной реализации: фольклористика, композиторское творчество, музыкальная педагогика, музыкально-критическая и публицистическая деятельность. Как фольклористы, и Кодай, и Людкевич стали пионерами (каждый в своей национальной культуре) в деле расшифровки народных песен с фонографических валиков. Как композиторы, они концентрировались прежде всего на вокальносимфонических и оркестровых жанрах, обработках народных песен; фундамент их индивидуального стиля образует опора на национальный фольклор. Как музыкальные педагоги, оба уделяли особое внимание развитию слуха через хоровое пение. Как музыкальные критики и публицисты - поднимали на страницах печати животрепещущие вопросы текущей музыкальной жизни.

Основные результаты и выводы исследования. 3. Кодай и С. Людкевич - представители древних национальных музыкальных культур, в начале ХХ века вышедших из-под имперского влияния. И если венгерская культура в условиях независимого государства благодаря Б. Бартоку и З. Кодаю освободилась от немецкого влияния, то украинская (в частности, галицкая), «уходя» от АвстроВенгрии, попала под советский пресс и осталась колониальной. Этим во многом объясняются отличия способов реализации и конкретных результатов фольклористической, композиторской, педагогической и просветительской деятельности 3. Кодая и С. Людкевича - выдающихся сыновей своих народов.

Ключевые слова: сравнение, универсальная личность, Золтан Кодай, Станислав Людкевич, венгерская и украинская музыкальная культура. 